\title{
Law, Politics, and the Military: Towards a Theory of Authoritarian Adjudication
}

\author{
Cosmin Cercel $^{1}(\mathbb{D}$ \\ ${ }^{1}$ University of Nottingham School of Law, Nottingham, United Kingdom \\ Corresponding author: cosmin.cercel@nottingham.ac.uk
}

(Received 08 September 2021; accepted 23 September 2021)

\begin{abstract}
This Article explores both theoretically and historically the core features of authoritarian adjudication. It attempts to offer an ideal type of what could mean a full assertion of authoritarianism in the context of adjudication. It aims to do so by first highlighting the value of insights that critical legal history can bring to the current discussion of populism. Second, it explores the paradigm of the exception that it aims to revise and ground in a historical analysis of the interwar period. Third, it considers the intellectual and practical lines of continuity between current reactions to the pandemic and the historical role of the military in modernity by drawing on the example of Romania. In a final part, it provides a reflection on the confusion between law, politics, and military concerns as a specific feature of modern authoritarianism.
\end{abstract}

Keywords: Constitutionalism; authoritarianism; legal theory; legal history; state of exception; separation of powers; rule of law

\section{A. Introduction}

The current crisis affecting polities in Europe and beyond has not only unraveled the limits of the neoliberal socio-economic project ${ }^{1}$ that has been dominant during the last decades, but has also put into question the basic legal infrastructure that supported it. From the rise to power of authoritarian leaders in United States, Central, and Eastern Europe to the emergence on the political stage of movements with explicit anti-liberal projects in the West, as well as the politico-legal reactions to the ongoing COVID-19 threat, the present crisis represents a drive undermining the values of liberal democracy and the liberal regimes of legality.

As recent research has shown, ${ }^{2}$ both core constitutional principles such as the separation of powers or parliamentary sovereignty as well as classical frames of legality such as human rights universalism and equality before the law are being challenged or reversed. In the wake of the ongoing COVID-19 crisis, these trends have been sharpened further to unprecedented levels as polities attempted to respond to the urgency of the pandemic threat. For instance, constitutional protections concerning the exercise of fundamental rights have been temporary suspended. Emergency legislative mechanisms ${ }^{3}$ have been put in place. As a result, executives all over Europe

\footnotetext{
Cosmin Cercel Associate Professor in Law at the University of Nottingham School of Law, PhD (Sorbonne), LLM (Sorbonne), LLB (Bucharest/Sorbonne).

${ }^{1}$ Pierre Dardot \& Christian laval, The New Way of the World: On Neoliberal Society (2013).

${ }^{2}$ Kim Lane Scheppele, Autocratic Legalism, 85 U. CHI. L. ReV. 545 (2018).

${ }^{3}$ See, e.g., Loi 2020-0072 of March 23, 2020 on the French Statute of Emergency for Facing the Covid-19 Epidemic, JournaL officiel de la Republique Française [J.O.] [Official Gazette of France], Mar. 24, 2020. 
secured sweeping powers through either exceptional regulations or blank checks in organizing the protection of the constituents of the state. ${ }^{4}$

It should be noticed from the outset that the ongoing public health crisis does not take place in a historical or politico-legal vacuum, but rather it unfolds against the background of a series of seemingly novel trends in constitutional law and electoral politics. These tendencies have been read as heralding an authoritarian turn in constitutional praxis if not design. Unsurprisingly, they raised a great deal of concern within the fields of comparative constitutional law and comparative politics. Understood and often described as forms of populism, such tendencies seemingly signal a growing discontent with the legal and political status quo. They also mark a regression at the level of political ideologies and constitutional imaginaries, in stark contradistinction with the established politico-legal status-quo specific to the last two decades. ${ }^{5}$

We can thus witness a return of the nation-state as a core discursive trope within the processes of legitimation of state power. Moreover, there is a perceived and evidenced resurgence of nationalism and xenophobia in societies otherwise regulated by supranational bodies. ${ }^{6}$ Such political strands have furthered a normalization of various ideological tropes connecting ethnicity to citizenship. ${ }^{7}$ These trends point towards a specific rupture with the ideological consensus that have officially organized law and politics in Europe since the demise of state socialism in the late 1980s.

However, as worrying as these new practices are-and indeed the ongoing reaction to the COVID-19 crisis is worrying - they are also a testimony for the theoretical scarcity of the existing paradigms within the field of constitutional theory when faced with major disruptions. The recent flourishing field of populist studies_-presumably soon to be followed by a longer thread of "crisis of democracy" studies-highlight the limit of the theoretical frames and conceptual paradigms that have fashioned the legal canon since the time of the fall of the Berlin wall, if not from the very early years of the post-war period.

As such, the ominous lurch towards overt authoritarian practices-from challenges to judicial independence ${ }^{8}$ and academic freedom, ${ }^{9}$ to xenophobia, ${ }^{10}$ and the questioning of legal certainty ${ }^{11}$ -has been read through the lenses of populism. ${ }^{12}$ Concepts such as populist constitutionalism, ${ }^{13}$ autocratic legalism, ${ }^{14}$ and stealth authoritarianism ${ }^{15}$ have now become common references for addressing changes within the structures and praxis of states in Central Europe and even beyond.

\footnotetext{
${ }^{4}$ Such as is the case of the Statute on protecting against the coronavirus in Hungary. For a translation of this text, see Hungarian Spectrum, Translation of draft law "On Protecting Against the Coronavirus," https://hungarianspectrum.org/ 2020/03/21/translation-of-draft-law-on-protecting-against-the-coronavirus/. In Romania, a presidential decree grounded constitutionally in the Article 93 of the Romanian Constitution of 1991 and legally in an emergency ordinance of 1999 and a statute of 2004 has been issued on March 16th. See, Decree Declaring the State of Emergency on Romanian Territory, No. 195, M. Of., No. 212, Mar. 17, 2020.

${ }^{5}$ Enzo Traverso, The New Faces of Fascism: Populism and the Far Right 3-41 (2019).

${ }^{6}$ See Roger Griffin, Interregnum or End Game? The Radical Right in the "Post-Fascist" Era, in The PopUlist RadiCAL Right: A ReAder 5-21 (Cas Mudde ed., 2017).

${ }^{7}$ Farida Fozdar \& Mitchell Low, “They Have to Abide by our Laws ... and Stuff”: Ethnic Nationalism Masquerading as Civic Nationalism, 21 NATIONS \& NATIONALISM 524-43 (2015).

${ }^{8}$ See ECJ, Case, C-619/18, Comm'n v. Republic of Poland \& Others, ECLI:EU:C:2019:531 (June 24, 2019) https://curia. europa.eu/juris/liste.jsf?num=C-619/18.

${ }^{9}$ See Andras L. Pap, Democratic Decline in Hungary: Law and Society in an Illiberal Democracy (2018).

${ }^{10}$ See ECJ, Case C- C-715/17, Comm'n v. Republic of Poland and Others, ECLI:EU:C:2020:257 (Apr. 2, 2020) (not yet published).

${ }^{11}$ See European Commission for Democracy Through Law, Romania: Opinion on the Emergency Ordinances GEO No.7 and GEO No. 12 Amending the Laws of Justice (June 24, 2019), https://www.venice.coe.int/webforms/documents/default.aspx? pdffile $=$ CDL-AD(2019)014-e.

${ }^{12}$ Jan-Werner Müller, What is Populism? 19-20 (2016).

${ }^{13}$ See David Landau, Populist Constitutions, 85 U. CHI. L. Rev. 521 (2018); Paul Blokker, Varieties of Populist Constitutionalism: The Transnational Dimension, 20 GERMAN L. J. 332 (2019).

${ }^{14}$ See Kim Lane Scheppele, supra note 2.

${ }^{15}$ See Ozan O. Varol, Stealth Authoritarianism, 100 IowA L. REv. 1673 (2015).
} 
For their part, the ongoing state-sanctioned reactions to the pandemic, going as far as to enabling government by decree or transferring police and administrative powers from civilian authorities to military ones, have been so far read under the heading of "protective" or "special' powers," 6 emphasizing at the same time their ambiguous position within constitutional frameworks, as powers at the limits of the "normal" functioning of the state's apparatus.

At closer inspection, the recent measures taken under the declared goal of tackling the pandemic overtly challenge the supposedly diffuse dimension of the existing authoritarian practices already in place. They also expose a line of continuity between nationalist rhetoric, legal and constitutional praxis, and deeper-seated ideological tropes that have been part of our constitutional histories in Europe since the end of 19th century. To be more specific, in the wake of the unfolding pandemic, foundational concepts of constitutional law and legal theory, with a heavy symbolic and historical weight - territory, population, and sovereign power-have emerged once again on the politico-legal stage as matters of public concern and certainly as matters of academic debate, ${ }^{17}$ recuperated from their seemingly established and antiquarian uses.

Moreover, the particular historical sequence to which they belong, one that have been marked by the series of crises befalling Europe since the refugee crisis of 2015 including: The terrorist threat of 2015-2016, the Brexit imbroglio and the veer towards populist rule in Hungary, Poland, and elsewhere, opens rather obvious lines of inquiry in relation to the specific regime of historicity. ${ }^{18}$ The present acceleration of historical processes towards a denouement that takes the form of the state of exception, determined as it is by the objective existence of a "sanitary" threat, is able to draw our attention towards the very core of the problems that have befallen the legal and institutional frameworks of European polities.

In this Article I want to explore both theoretically and historically what could be termed the core features of authoritarian adjudication. I thus intend to offer an ideal type of what could mean a full assertion of authoritarianism in the context of adjudication. I shall do so by first highlighting the value of insights that critical legal history can bring to the current discussion of populism. Second, I turn towards the paradigm of the exception that I intend to revise and ground in the analysis of the interwar period. Third, I consider the intellectual and practical lines of continuity between current reactions to the pandemic and the historical role of the military in modernity by drawing on the example of Romania. In a final part, I reflect on the confusion between law, politics, and military concerns as a specific feature of modern authoritarianism.

\section{B. The State of Exception and Critical Legal History}

Within the existing context, despite important efforts of scholars in constitutional law and jurisprudence to come to grips with the nature of the threat, I believe that a core question seems to have been elided. What was left unchallenged and effectively under-problematized, was unsurprisingly, the place and function of legal normativity within the democratic backsliding. Otherwise said, law - as a discourse and practice with its specific grammar, symbolic power, and historical legacyhas been taken for granted as if being in a natural symbiosis with democracy. As it has been emphasized even in the wake of all the current devaluation of the democratic form: "Liberalism is ... a constitutive precondition for democracy, which provides for the rule of law, checks and balances, and guaranteed fundamental rights." 19

\footnotetext{
${ }^{16}$ See, e.g., COVID 19 and States of Emergency, VERFASSUNGSBLOG, https://verfassungsblog.de/category/debates/covid-19and-states-of-emergency-debates/ (last visited Mar. 16, 2020).

${ }^{17}$ See Universidad Nacional Autónoma de México, COVID-19 and Constitutional law (José Ma. Serna de la Garza ed., 2020).

${ }^{18}$ François Hartog, Régimes d’historicité: PréSentisme et eXPériences dU temps SeUil 27-29 (2003).

${ }^{19}$ Gábor Halmai, Populism, Authoritarianism and Constitutionalism, 20 German L. J. 296, 311 (2019).
} 
The intellectual origins of this particular politico-legal stance reach back to the now ages-old positioning of a necessary connection between constitutional procedures and democracy of a Kelsenian strand, ${ }^{20}$ as well as the Habermasian emphasis on the neutral medium of legality, able to deal away with the materiality of conflicts and to provide for a rational articulation of dissent. ${ }^{21}$ From the standpoint of the intellectual history of legal thought, this line of inquiry seems not to be able to tackle either the nature of the threat raised by the recurrence of authoritarian assertions in the public sphere and constitutional law, nor its particular forms. What we need then seems to be a widening of the conceptual framework of understanding authoritarianism and a refocus on the failings of the relationship between law and authoritarian politics.

Against the prevalent view described above, I claim that there is another way of looking at the current politico-legal crisis, by focusing on the traditional object of study of legal historians and theorists- that is, law. I consider that law, perceived and construed in its intellectual history and institutional practice, is part of the same series of shortcomings of our polities that are situated both within and beyond questions of political mobilization and constitutional identity. Rather than being a neutral medium, or simply a mediator of the existing articulated political movements within European polities, law is itself an active part of the process of democratic breakdown, by implicitly and, at times, explicitly, supporting and fueling a specific worldview that is far from being at odds with the ostensible attacks on liberal legality.

In this Article, my argument is twofold. First, I take into account law's internal inconsistency, by recuperating the critical legal studies insistence on its internal indeterminacy within the specific conditions of late capitalism. Second, I will situate this foundational notion of indeterminacy both historically and conceptually within a trajectory that necessarily traces back to a specific moment of disruption within European history. At the end of this examination, I aim to unearth and bring to the fore of the debate the core constituents of the authoritarian features that have been nested at the center of our constitutional and legal frameworks, namely the specific arrangement and conflation between legal normativity, military power, and politics.

To this end I intend to draw on the theoretical insights of the Critical Legal Studies movement and on the work of Giorgio Agamben. Accordingly, I intend to reconnect and reflect on the potential critical legal theory has for analyzing the present crisis of liberal legality, by insisting on the indeterminacy of law and its relation to politics. Within the intellectual context of the "end of history" that have spanned and gained hegemony since the fall of the Berlin wall and the obscure disaster ${ }^{22}$ of the fall of communism, the old Critical Legal Studies (CLS) insights into the indeterminacy of law ${ }^{23}$ were soon to be deemed obsolete, because of the newly found confidence in liberal legality. Moreover, the stark legal skepticism of the CLS movement towards the law failed to resonate with the apollonian dream of constitutional patriotism ${ }^{24}$ insofar as it challenged the very medium through which European integration was made. There was also perhaps very little that could have seemed directly transferable to the nomothetic reality of continental law $^{25}$ with its sacralization of legal texts, ${ }^{26}$ even more of constitutional ones. And, as a matter of style, the rather noisy overtones of the critical revolt did not find much echo within the amphitheaters of the age-old schools of law on the continent. Last, but not least, the implicit or explicit Marxist tropes present in some of the CLS positions were also very little

\footnotetext{
${ }^{20}$ Hans Kelsen, Foundations of Democracy, 66 Ethics 1 (1955).

${ }^{21}$ Jurgen Habermas, Moral Consciousness and Communicative ACtion (1993).

${ }^{22}$ Alain Badiou, D’un désastre obscur: Sur la Fin de la Vérité d’Etat (1998).

${ }^{23}$ See Mark Tushnet, A Note on the Revival of Textualism in Constitutional Theory, 58 S. CAL. L. REv. 583, 700 (1985) ("All forms of textualism suffer from a fatal defect: they give us a Constitution without the politics.").

${ }^{24}$ Cosmin Cercel, The Other Otherwise: Law, Historical Trauma and the Severed Gardens of Justice, 8 Pólemos: J. L., Literature \& Culture, 275, 281 (2014).

${ }^{25}$ David Fraser, The Day the Music Died: The Civil Law Tradition from a Critical Legal Studies Perspective, 32 LoY. L. REV. 861 (1987).

${ }^{26}$ Pierre Legrand, Antiqui Juris Civilis Fabulas', 45 UnIv. Toronto L. J. 311, 317 (1995).
} 
welcomed in a context that was building its symbolic limits in relation to the communist experience and was ready to elide references to Marx. ${ }^{27}$

This lost encounter prevented European legal scholars from approaching the law as an inconsistent assemblage of texts, decisions, and interpretive practices that do have a political value beyond the ostensible official one. Moreover, such a failed encounter effectively barred the possibility of problematizing the law as a "system at war with itself," as a patchwork of texts that cannot be subsumed to general principles, let alone a coherent narrative, without the imposition of a great deal of hermeneutic pressure. Be it as it may, the fact that such a position stayed marginal within the general field of jurisprudence and within what later became the field of constitutional theory, does not mean that these insights were easily dismissed, derided, or ignored.

It is indeed, at the margins of the legal discipline that a reflection on the status of legality and the form of law has started to be articulated, ${ }^{28}$ that considered and furthered the specific conundrum that connects law with authority. In a rather distorted and undisciplined dialogue with political philosophy that resembled in many respects a border trafficking of knowledge, important questions have been addressed on both sides of the continent within and outside the CLS tradition and what is rightly or wrongly coined as continental theory. It is perhaps due to Jacques Derrida's seminal text Force of $\operatorname{Law}^{29}$ that a connection between the foundational questions raised by the CLS was made with a continental intellectual tradition of legal skepticism assembling figures as different as Walter Benjamin ${ }^{30}$ and Carl Schmitt. ${ }^{31}$

The revival of the work of the former Crownjurist of the Third Reich around the same time, which is a subject worth the interest in itself insofar as it was largely due to political philosophers affiliated to the left, ${ }^{32}$ did play a key role in producing a questioning around the status of constitutional theory in its relation to politics and brought to some extent law within the purview of critical theory. A final stage within this trajectory was Giorgio Agamben's rereading of Carl Schmitt's concept of the state of exception.

Assembled as a number of six instalments of the series Homo sacer, published between 1995 and 2014, the work of the Italian philosopher seeks for the arché of power and authority beyond the usual politico-legal paradigms and attempts to reconstruct the original meaning of these concepts within the Western tradition. As influential and compelling this procedure is in the field of political philosophy, the publication of the first two instalments of this oeuvre is central for the investigation I propose here, be it only because they attempt to tackle head-on core questions for jurisprudence and constitutional theory.

Indeed, both Homo sacer $1^{33}$ and the State of Exception ${ }^{34}$ bring to the fore the very inconsistency of law, understood as a system of signification. The core concept, that is the state of exception, an otherwise overlooked institution within constitutional theory at the time of the publication of the first instalment of this series, ${ }^{35}$ embodies precisely this limit point of the state of legality. In relation to the moving reality, the law has to be suspended in order to be applied. This

\footnotetext{
${ }^{27}$ Symptomatic for this "end of history" sensitivity, see Martin Krygier, Marxism and the Rule of Law: Reflections After the Collapse of Communism, 15 L. \& Soc. INQUIRY 633 (1990).

${ }^{28}$ See, e.g., Costas Douzinas, Peter Goodrich \& Yifat Hachamovitch, Politics, Postmodernity and Critical LEGAL STUDIES (1994).

${ }^{29}$ JaCQues Derrida, Force De LoI (1994).

${ }^{30}$ Walter Benjamin, Critique of Violence, in Selected Writings (Marcus Bullock \& Michael W. Jennings eds, 1996).

${ }^{31}$ DERRIDA, supra note 29 , at 84-98.

${ }^{32}$ Chantal Mouffe, Penser la démocratie moderne avec, et contre, Carl Schmitt, 42 REVUE FRANÇAISE DE SCIENCE POLITIQUE 83 (1992).

${ }^{33}$ Giorgio Agamben, Homo Sacer: Sovereign Power and Bare Life (D. Heller-Roazen trans., Stanford University Press, 1998) (1995)

${ }^{34}$ Giorgio Agamben, State of Exception (Kevin Attell trans., University of Chicago Press, 2005) (2003).

${ }^{35}$ Yet knowing an intellectual history of its own from the publication of Theodore Rainach's De l'état de siege in 1885 , through Carl Schmitt's Dictatorship in 1921 and the host of constitutional law treatises written during the interwar across Europe in attempting to systematize the emergency legislation aimed at tackling the threats posed to the status quo by both
} 
suspension cannot be reduced to being merely a liminal practice necessary as it may be for the grounding of law in social reality, but actually able to reveal both the vacuous feature of legality and its reliance on an exterior, be it political, economic, or otherwise, that is already singled out or subtracted from the ambit of the law. As he writes, "[1]aw is made of nothing but what it manages to capture inside itself through the inclusive exclusion of the exception: it nourishes itself on this exception and is a dead letter without it." ${ }^{\prime 6}$

According to these lines, legality emerges as a battleground for opposing tendencies that have structured political modernity in their attempt of articulating life within the structure of the polis. At its core, Agamben's project is and should be read as a philosophical intervention that aims at founding an alternative political ontology, by describing the domain of politics as a space of the articulation between $z o \bar{e}$ and bios. ${ }^{37}$ However, his insistence on the state of exception as a central feature of legality is of crucial importance to the understanding of the current jurisprudential conundrum. His rather poignant emphasis on the state of exception, albeit based on a historically sparse analysis, does at least point towards two central foundational moments in the life of modern law, namely the experience of the interwar and the Holocaust. As embodiments of the destruction of legality and civilization, these historical examples also present the ambivalent place of law $^{38}$ and repression $^{39}$ in modernity. As it has been rightly argued, "Agamben's reading of law and Auschwitz ... permits us . . . to better understand the ethical and legal implications of the culmination of bio-power." ${ }^{40}$ Following the path opened by Foucault and Arendt, Agamben thus attempts to connect the hold of power and politics over life, over "man-as-living-being" 41 and the experience of totalitarianism by blurring the dividing lines between democracy and totalitarianism.

Analyses within the legal field tackling this historical legacy have been articulated as a field in its own right in a parallel, yet not entirely unconnected to the Agambenian investigation, trajectory since the turn of the century. Important questions about law's role within the context of dictatorial regimes and contexts existing in Europe during the interwar period have been raised. ${ }^{42}$ As such, central questions about the role of the legal framework and that of judges in the context of the Holocaust have been addressed, together with more refined and details accounts of the symbolic, ideological, and material ways in which either constitutional law, criminal law, or private law has reacted or has been molded by the experience of generic fascism, national socialism, or by the ideologies of collaborationist regimes during the dark times of Nazi hegemony in Europe. ${ }^{43}$

Attempts at connecting these questions to the experience of law within the communist context have also been made by problematizing the resilience of the legal form within regimes whose ideological creeds boasted its disappearance. ${ }^{44}$ There is of course an arduous task that lays before legal historians and historians as such in order to connect these critical legal histories of the law with the social history of these regimes, as well as to construct a more refined paradigm in addressing the question of continuity of what was aptly labelled as tainted law. ${ }^{45}$ Moreover, there is still room, and this is the wager of the current intervention, to connect both the philosophical, legal

\footnotetext{
right wing and left-wing agitation. See, e.g., ThÉOdore REINACH, L'ETAT DE SIEGE: ÉTUdE HISTORIQUE ET JURIDIQUE (1885); CARL SCHMitT, Dictatorship (Michael Hoelzl \& Graham Ward trans., 2014) (1921).

${ }^{36}$ AGAMBEN, supra note 33 , at 22.

${ }^{37}$ Id. at 4 .

${ }^{38}$ David Fraser, Law After Auschwitz: Towards a Jurisprudence of the Holocaust, 212-13 (2005).

${ }^{39}$ Enzo Traverso, The Origins of Nazi Violence (2003).

${ }^{40}$ David Fraser, Dead Man Walking: Law and Ethics after Giorgio Agamben's Auschwitz, 12 INT'L J. SEMIOTICs L. 397,406 (2000).

${ }^{41}$ Michel Foucault, Society Must be Defended 242 (1997).

${ }^{42}$ Darker Legacies of Law in Europe: The Shadow of National Socialism and Fascism Over Europe and Its Legal Traditions (Christian Joerges \& Navraj Singh Ghaleigh eds., 2003).

${ }^{43}$ FAscism and Criminal Law: History, Theory, Continuity (Stephen Skinner ed., 2015); IdEOlOgy AND CRIMINAL Law: Fascist, National Socialist and Authoritarian Regimes (Stephen Skinner ed., 2019).

${ }^{44}$ Cosmin Cercel, Towards a Jurisprudence of State Communism: LaW and the Failure of Revolution (2018).

${ }^{45}$ Stephen Skinner, Tainted law? The Italian Penal Code, Fascism and Democracy, 7 InT'L J. L. ConTEXT 423 (2011).
} 
theoretical and historical insights explored so far in offering a map for future research able to capture the specific crisis of legality that we are experiencing.

Accordingly, from the standpoint of legal history, the current predicament bears a stark resemblance with the breakdown of democracy during the interwar era and it does indeed entertain intellectual lines of continuity with this period. ${ }^{46}$ Focusing on the phenomenon of populism ${ }^{47}$ and operating with a limited timeframe the existing constitutional theory literature has constantly overlooked and eschewed the legal historical experience of authoritarianism.

Yet, authoritarianism as both a threat and a distortion of the liberal nomos, has happened before and little if anything has been done to investigate at least the formal isomorphism that our polities share with the breakdown of democracy within the 1930s. As I have noted elsewhere, ${ }^{48}$ there is an uncanny resemblance that the contemporary context bears with the spirit of Weimar, either in terms of jurisprudence, legal praxis, and liberal ethos. However, beyond the centrality of the Weimar model in approaching the question of the dissolution of democracy, ${ }^{49}$ and the importance of the Schmitt-Kelsen opposition as a jurisprudential embodiment of this historical sequence, the focus is still too narrow. What we seem to lack is a broader framework of understanding the tension between liberal legality and right-wing authoritarianism beyond the borders of the German legal science, and as a symptom of a political reshuffling in times of crisis.

In other words, we need to understand in its proper frames and grammar the thought that has shaped the fall of Europe in the shadow of authoritarianism during the interwar. In doing so, I follow the otherwise programmatic injunction and intimation that I propose in relation to the state of exception as a paradigm and a frontispiece able to guide us in the reading of the present. ${ }^{50}$

Accordingly, I believe that within the legal theoretical field, we already have two important conceptual pillars able to provide a solid framework for the analysis of both past and present regimes of legality in crisis. As such, "on one hand, there is the very concept of the state of exception, with both its intellectual genealogy, and material history of practices. On the other, there is nothing else than the status of the law as a field of knowledge and as a praxis molded by historical experience." 51

\section{The Paradigm of Exception Revisited: Law, Politics, and Military}

For the purposes of this Article, I will look at the historical experience of connivance between law, political power, and military praxis that has haunted the European interwar period. I am interested in unearthing the relationship that these otherwise distinct spheres that under the traditional politico-legal conditions prior to the Great War were kept relatively separate. Even if the interwar period has witnessed a proliferation of the state of exception and a surge in executive and exceptional powers, one should perhaps recall that the historical origins of this nexus emerge on the trail of the 19th century revolutionary movements. ${ }^{52}$ It is first following the French revolution of 1789 that the ur-type of modern legislation on the state of exception emerges as a state of siege limited to areas under military threat. Later on, after the June uprising in 1848 , its form is extended also to

\footnotetext{
${ }^{46}$ Enzo Traverso, The New Faces of Fascism (2019); Ideology and Criminal LaW: Fascist, National Socialist and Authoritarian Regimes (Stephen Skinner ed., 2019).

${ }^{47}$ David Landau, Populist Constitutions, 85 U. CHI. L. Rev. 521 (2018).

${ }^{48}$ Cosmin Cercel, The Destruction of Legal Reason: Lessons from the Past, 89 ACTA Universitatis LodZiEnsis Folia IURIDICA 15 (2019).

${ }^{49}$ See, e.g., Lars Vinx, The Guardian of the Constitution : Hans Kelsen and Carl Schmitt on the Limits of Constitutional Law (2015); Augustin Simard, La loi désarmée: Carl Schmitt et la controverse légalité/ LÉGITIMITÉ SOUS LA RÉPUBLIQUE DE WEIMAR (2009); WEIMAR: A JURISPRUdENCE OF CRISIS (Arthur J. Jacobson \& Bernard Schlink eds., 2000).

${ }^{50}$ Cosmin Cercel, "Through A Glass Darkly": Law, History and the Frontispiece of the Exception, in, STATES OF EXCEPTION: Law, History, Theory 34-54 (Cosmin Cercel, Gian-Giacomo Fusco \& Simon Lavis eds., 2020).

${ }^{51} I d$.

${ }^{52}$ Cosmin Cercel, Karl Marx's Concept of Dictatorship', in RESEARch HaNdBoOK ON LAW AND MarXISM (forthcoming, Umut Oszu \& Paul O'Connell eds., 2021).
} 
various political threats, being "regulated as an organic institution" 53 as early as 1849 . The French model of the state of siege was an epitome of the continental model of accommodation of emergency and served as an example for a host of legal systems in Europe, Latin America and beyond. ${ }^{54}$ The place of the military in this framework is quite clear, as once a threat to the state was perceived, all police, crime-investigating and administrative powers were transferred from civilian authorities to military ones. ${ }^{55}$

I thus am interested in delineating the symbolic locus of adjudication within such a frame and against the background of the blurring lines specific to the state of exception. Last but not least, I intend to reflect on the role of judicial praxis that takes place at the core of this suspension of the symbolic structures of legality. In this way, my attempt is to isolate and define a limited conceptual and practical sphere of legal adjudication able to capture the paradigmatic operation of law as an authoritarian praxis. This investigation should be able to clarify what is at the core of the dissolution of judicial independence in authoritarian setting, namely the function of the judge as an official acting towards the imposition of the law.

To begin with I hasten to note that the paradigm of exception developed by Agamben neither exhausts nor blocks a jurisprudential or material historical meaning of the exception. On the contrary, it enables the possibility of exploring further the practice of the suspension of legal protections as an operation of the law itself. And it is precisely this paradox that has constantly been disregarded by lawyers and political philosophers following Agamben, that the exception reveals the limits and the tensions within legality as such, and perhaps the limits of the Western legal praxis at the same time.

To be sure, there is in this position an indelible intellectual, if not historical, connection to the jurisprudence of crisis specific to the interwar period. This connection has a clear grounding in the discussion of both Schmitt's concept of exception and Benjamin's search for a revolutionary violence. While the German jurist was seeking to find the true locus of sovereignty in the suspension of the law, the philosopher was seeking to be able to identify a form of revolution unadulterated by the limits of the state. Yet, the concept of exception also knows a rather unexplored line of continuity with the now established jurisprudential position of Hans Kelsen.

Indeed, the inconsistent and inconclusive description that Kelsen offers within the first edition of The Pure Theory of Law to the relationship between validity and efficacy is symptomatic for the ways in which liberal legality was conceptualized within the interwar period. ${ }^{56}$ To put it simply, in order for validity to be possible, a specific form of legal — that is socially and politically significant - effectiveness has to operate. ${ }^{57}$ The theoretical purity and its otherwise intellectually sound frame of interpretation of legality has to give way to an extra-legal notion of effectiveness that finds itself outside the ambit of the law, yet it is central for its existence. In a sense, Kelsen's heterodox Kantianism is forced to recognize, albeit reluctantly and inconclusively, the presence of an exterior to the legal order that determines its very existence-insofar as validity is the specific form of existence of the legal norms.

It is not a mere historical accident that the formulation of this thesis took place in a time and against a background in which exceptional measures have become an important part of the life of the polities in Europe. Not only overtly authoritarian regimes such as Fascist Italy and the Soviet Union were embarked in a process of reframing legality according to the lines of a recasting of dictatorial powers, followed by a flurry of overtly authoritarian regimes and the rise to power of

\footnotetext{
${ }^{53}$ Karl Marx, The Eighteenth Brumaire of Louis Bonaparte, IN KARL MARX \& FrIEDRICH ENGELS, COLLECTED WORKS, VOL. 11 99-197 (Lawrence \& Wishart, 1979), 130 (1852).

${ }^{54}$ Oren Gross \& Fionnuala Ní Aolain, Law in Times of Crisis: Emergency Powers in Theory and Practice 26-30 (2006).

${ }^{55}$ Clinton Rossiter, Constitutional Dictatorship: Crisis Government in Modern Democracies 80-86 (1948).

${ }^{56}$ Hans Kelsen, Introduction to the Problems of Legal Theory 58-60 (Bonnie Litschewski Paulson \& Stanley Paulson trans., Oxford University Press, 1992) (1934).

${ }^{57} I d$. at 60 .
} 
National Socialism, but also the self-professed liberal democracies of the interwar years were following a rather similar trend. The constitutional concept of militant democracy ${ }^{58}$ as well as the long history of exceptional measures taken in France or Romania even before the surrender to Germany and the instauration of the Vichy regime ${ }^{59}$ or the declaration of the dictatorship, bear witness for the existence of such a trend, which was marked by a search for enabling precisely the extra-legal efficiency needed for legal validity. In Schmitt's words, "for a legal order to make sense, a normal situation must exist." 60

This is not to say that there were no significant differences arising from ideological, political, and socio-economic conditions across the countries of the continent, or that the legal cultures and grammars of construing and imagining the nature of the exception within the legal orders were insignificant. It is rather to say that looked at from the standpoint of a purely formal and structural analysis, we witness in the interwar period a turn towards a series of exceptional measures that sought to revise and reconstruct the meaning of legality within European polities. Moreover, this trend does indeed trace back to a transnational history of both global economic and social tensions —of which the financial crisis of 1929 is only an aspect-as well as to the emergence of a modern field of comparative constitutional law and legal theory that was crossing state borders. Looked at from this perspective, as scarce, rigid, and epithelial it may be-insofar as it silences the local histories of framing the exception and of resisting its powers-we are able to grasp its significance for our present situation. The features of the dissolution of legality within this period of time do reveal the central aspects of the recasting of state power, as a sovereign power that is slowly, but steadily unfettered within areas such as criminal repression, administrative law, citizenship and protection of the constitutional order. What we are witnessing in these instances is that there is a sovereign power that is resurgent within the very framework of modern legality. At its core there is a restatement of the military function as a form of protection of the population and as a deterring force mustered against internal and external enemies. There is, therefore, a need to explore both theoretically, and historically, the main features of this recent resurgence of sovereign power in its connection with military power in the recent ongoing context marked by the reactions to the pandemic. Driven by the idea that sovereign power in relation to the law still needs a form of legal and judicial legitimation, my analysis turns towards the legal and political coordinates of the role of judiciary and executive under the conditions of the pandemic, attempting to place them in a legal historical context marked by the blurring between law, politics, and military.

\section{Judging and Governing Within the Exception}

While the deeper philosophical and jurisprudential significance of this position remain to be discussed further, especially in relation to the historical and cultural embeddedness of the exception, the main point of my intervention is related to the specificities of the legal instantiations of the state of exception in interwar Romania. The trajectory of legality under the strain of exceptional measures in this context could shed some further light on the role of adjudication in authoritarian setting and the paradigm of the state of exception. Given the specific context in which my intervention is taking place, it calls for a consideration of the ideological retrenchment towards the nation-state. Moreover, this archaeological analysis, trying to seize the origin of the current politico-legal predicament, can also establish lines of continuity between regimes of legality and as well as highlight the blurred symbolic lines that seemingly separate procedural democracy from its authoritarian other. As such, my interest lies in delineating within the functioning of the

\footnotetext{
${ }^{58}$ As Loewenstein put it in 1937: "State of siege means, even under democratic constitutions, concentration of powers in the hands of the government and suspension of fundamental rights." Karl Loewenstein, Militant Democracy and Fundamental Rights I, 31 Am. Pol. Sci. Rev. 417, 432 (1937).

${ }^{59}$ Roger Bonnard, La guerre de 1939-1940 ET LE Droit Public (1940).

${ }^{60}$ Carl Schmitt, Political Theology 13 (George Schwab trans., MIT Press, 1985) (1922).
} 
exception itself an unfinished process of suspension of legality, in which normative structures shift rather than disappear.

To be sure, while unlike Poland and Hungary, Romania does not feature within the EU countries that have been singled out as veering towards authoritarianism, and the official concerns uttered by EU bodies concern specifically questions related to corruption, this does not necessarily entail that the rule of law and legality as such were settled matters even before the pandemic. Not only the Cooperation and Verification Mechanism (CVM) as a matter of compliance with European law is still in place, ${ }^{61}$ but also the various political crises of the last decade have been at the origins of a number of advisory opinions of the Venice Commission on the rule of law $^{62}$ and to a rather long and inconsistent case-law arising from constitutional review. More recently, the European Court of Justice (ECJ) clarified that the provisions of CVM are binding and "are intended to ensure that Romania complies with the value of the rule of law, set out in Article 2 of the Treaty on European Union (TEU)." ${ }^{\prime 3}$ Testimony to the fact that the threat to the liberal legal infrastructure is diffused on the whole political spectrum and not the monopoly of the once monolithic Social Democratic party is the little noticed fact that only weeks before the COVID-19 crisis unfolded, the self-styled liberal government has passed no fewer than 25 pieces of emergency-legislation in one day! ${ }^{64}$ Such practices were noted in the 2020 European Commission's Report on the Rule of Law, which highlighted that "the ordinary legislative process is often side-lined by the widespread use of Government Emergency Ordinances." ${ }^{\circ 5}$ Furthermore, it might be true that Romania's stance towards EU was, regardless of some isolate flirting with Euroscepticism of the previous government, rather unchanged and in support of the supranational project.

Yet this trajectory does not necessarily entail that the polity is immune to the ideology of the nation-state and its resurgence. On the contrary, the particular politico-legal conundrum raised by the public health crisis has reinforced the general perception of the polity as a territorially and culturally defined body that has to be protected from outside threat. ${ }^{66}$ These contemporary trajectories of the state under the pressure of emergency and the shift towards a reversal of legal safeguards bring to the fore the ambiguity of the exception as both a limit-concept of the legal order and as a legal practice at the limit of the rule-of-law sanctioned practices.

In this sense, it is useful to note how the exceptional measures issued in the context of the COVID-19 crisis reconstructed symbolically trends within the historical trajectory of the state. For instance, the legal basis of these measures was found in a Presidential decree declaring the state of emergency, which essentially placed policing, public order, and administrative support under the direct supervision of the Ministry of Internal Affairs. ${ }^{67}$ For its part, this decree was

\footnotetext{
${ }^{61}$ See European Commission, Report from the Commission to the European Parliament and the Council On Progress in Romania under the Cooperation and Verification Mechanism COM (2019) 499 final (Oct. 22, 2019).

${ }^{62}$ See Venice Commission, Opinion of 20 October 2018 on amendments to Romania's law No 303/2004 on the statute of judges and prosecutors, law No 304/2004 on judicial organisation, and law No 317/2004 on the Superior Council of Magistracy (Oct. 20, 2018) https:/www.venice.coe.int/webforms/documents/default.aspx?pdffile=CDL-AD(2018)017-e; Venice Commission, Opinion of 20 October 2018 on amendments to Romania's Criminal Code and Criminal Procedure Code, laws also affecting law No 78/2000 on preventing, detecting and sanctioning acts of corruption and law No 304/2004 on judicial organization (Oct. 20, 2018), https://www.venice.coe.int/webforms/documents/default.aspx?pdffile=CDL-AD(2018)021-e.

${ }^{63}$ ECJ, Joined Cases C-83/19, 127/19 \& 195/19, Asociația "Forumul Judecătorilor Din România", para. 178 ECLI:EU: C:2021:393 (not yet published).

${ }^{64}$ See e.g. Bogdan Neagu, BUCHAREST - What's in Government's Emergency Ordinances?, EURACTIV.RO https://www.euractiv. com/section/all/short_news/bucharest-whats-in-governments-emergency-ordinances/ (Last visited on August 4, 2021).

${ }^{65}$ European Commission, Rule of Law Report Country Chapter on the rule of law situation in Romania, SWD (2020) 322 final 15 (Sept. 15, 2020).

${ }^{66}$ As a somewhat marginal, yet significant detail, an order' issued by the Ministry of Internal Affairs pursuant to the Presidential decree declaring the state of emergency in March 2020 provided for the public broadcasting of the national anthem by vehicles of the police, the national gendarmerie and the border police on week-ends.

${ }^{67}$ Decree Concerning the Establishment of the State of Emergency, No. 195 of 16 March 2020, M. Of., No. 2020, 16 Mar. 2020 (Rom.).
} 
issued pursuant to a statute on the legal regime of the stage of siege and the state of emergency of $2004,{ }^{68}$ confirming the provisions of an emergency ordinance of $1999 .{ }^{69}$ Last, but not least, this legislation was provided for under the constitutional exception clause present in article $93 .{ }^{70}$ This legal dispositive can offer to an attentive reading an example of the continuity of legal concepts with a significantly convoluted history. To begin with, the central provisions of the emergency legislation related the exceptional measure to the existence of "grave dangers"71 that threatened either the sovereignty, independence or territorial integrity of the state in the case of the state of siege ${ }^{72}$ or the national security and the constitutional order, in the case of the state of emergency. ${ }^{73}$ Moreover, the exercise of a number of fundamental rights, including freedom of movement, speech, and association, was explicitly limited. ${ }^{74}$ It is worth noting in this respect that on the occasion of the declaration of the state of emergency Romania sought a derogation from the provisions of the European Convention of Human Rights. ${ }^{75}$

While theoretically distinct, considering the nature of the threat that they are designed to address, the institution of the state of siege and that of the state of emergency do share a number of conceptual and practical similarities. For its part, the state of siege arguably contemplates an external threat of military nature, ${ }^{76}$ while the state of emergency an internal one directed to the public safety or is generated by "natural disasters." 77 There is, however, a specific conflation of these institutions given the nature of the measures that seek to either limit, mitigate, or put an end to these dangers. As such, these measures consist in a transfer of powers from the remit of central and local civil administration to military authorities in the case of the state of siege or to special public authorities in that of state of emergency ${ }^{78}$ thus replicating the ur-type transfer of power specific to the French model of emergency since 19th century. ${ }^{79}$

In March 2020, the Ministry of Internal Affairs took on the task of central coordination of the lock-down measures while having the support of the Ministry of National Defence. ${ }^{80}$ In fulfilling these measures, the Minister of Internal Affairs issues a special type of normative administrative acts bearing the name of military ordinances. ${ }^{81}$ While, in essence, these regulations can be subjected to a judicial review by the courts under the application of administrative review of legality, ${ }^{82}$ they nonetheless can contain significant normative provisions that can go against statutory and even constitutional provisions, insofar as they have been issued pursuant to the clause of exceptional measures within the constitution itself. In short, the regulations do embody a legal paradox insofar as concerning their content they can be contra legem, while at the level of form they cannot possibly be normatively superior to a statute. The presence of this paradox is also mentioned by

\footnotetext{
${ }^{68}$ Statute Confirming the Emergency Ordinance Concerning the Legal Status of the Sate of Siege and of the State of Emergency, 1 Nov. 2004, M. O., No. 1052, 12 Nov. 2004 (Rom.).

${ }^{69}$ Emergency Ordinance Concerning the Legal Status of the State of Siege and the State of Emergency, 21 Jan. 1999, M. O., No. 22., 21 January 1999.

${ }^{70}$ Constituia Romaniei [Constitution] Dec. 81991 (Rom.).

${ }^{71}$ Statute Confirming the Emergency Ordinance, supra note 68, at art. 1

${ }^{72}$ See supra note 70 .

${ }^{73} \mathrm{Id}$.

${ }^{74}$ Statute Confirming the Emergency Ordinance, supra note 68, at art. 1; Emergency Ordinance, supra note 69, at art. 4.

${ }^{75}$ Derogation contained in a Note verbal from the Permanent Representation of Romania to the Council of Europe, dated 17 March 2020, registered at the Secretariat General on 17 March 2020, (Mar. 17, 2020), https://www.coe.int/en/web/conventions/ full-list 2 ? module $=$ declarations-by-treaty\&numSte $=046 \&$ codeNature $=0$.

${ }^{76}$ Statute Confirming the Emergency Ordinance, supra note 68, at art. 2; Emergency Ordinance, supra note 69, at art. 2.

${ }^{77}$ Statute Confirming the Emergency Ordinance, supra note 68, at art. 1.3; Emergency Ordinance, supra note 69, at art. 3.

${ }^{78}$ Statute Confirming the Emergency Ordinance, supra note 68, at art. 1.7; Emergency Ordinance, supra note 69, at art. 7

${ }^{79}$ Clinton Rossiter, Constitutional Dictatorship: Crisis Government in the Modern Demorcracies 90 (2002).

${ }^{80}$ Decree, supra note 67 , at art. 5(1).

${ }^{81}$ Statute Confirming the Emergency Ordinance, supra note 68, at art. 1.19; Emergency Ordinance, supra note 69, at art. 20.

${ }^{82}$ See, Bogdan Dima, How "military" are the military ordinances?, AUBD FORUM JURIDIC (2020), https://www.juridice.ro/ 677828/cat-de-militara-este-ordonanta-militara.html.
} 
Tímea Drinóczi and Agnieszka Bień-Kacała in the case of Hungary. As they write, “(b)y definition, regulations cannot modify statutory provisions. However, such . . . authorization can also be, incidentally, found." ${ }^{83}$ It is worth recalling in relation to Romania that the original text of 1999, now abrogated, considered that military ordinances themselves are endowed with "force of law."

Such a paradox is perhaps not the only marker of the ways in which the exceptional measures in place at this moment can be understood as embodying the wider jurisprudential concept of the state of exception insofar as they do hint to a central difficulty of the symbolic and normative dimension of the law to articulate itself in a coherent manner. Moreover, the conflation between disasters, imminent danger to the constitutional order, and the functioning of democracy or sovereignty, doubled as it is by the conflation between military powers and civilian ones, enables one to consider this moment as a part of a wider history of the theory and practice of exceptions. Moreover, the measures introduced by the decree declaring the emergency touched upon the administration of justice and hence the application of the law by limiting the activity of the courts in both civil and criminal law matters to only what is deemed to be urgent. ${ }^{85}$ In this respect, it is worth noting that under the strain of the exception, the activity of the courts was primarily reduced to a number of cases directly connected to the rules implementing the measures and concerns, foremost, matters related to repression of crimes connected to the nature of the threat. ${ }^{86}$

Ever since May 2020 the COVID-19 related measures have given rise to a number of constitutional review cases aimed at mitigating their effect on the exercise of fundamental rights. Worth noting in this context is the Decision no. 152/2020, explicitly declaring the provisions of the 1999 Emergency Ordinance to be constitutional with respect to the powers granted to the president. ${ }^{87}$ However, the Court also found that the Emergency Ordinance of 2020 violated constitutional provisions by creating extraordinary sanctions and punishments of misdemeanors. Moreover, by declaring the original Emergency Ordinance of 1999 constitutional in relation to the Constitution in force at that time, the Court did fall short of addressing the practice of military ordinances and merely curtailed the recent provisions concerning the application of fines. While insisting on the importance of constitutional limitations and safeguards, the Court has refrained from addressing the fundamental issue of how an Emergency Ordinance issued under the conditions of a miners' riot $^{88}$ and under a different constitutional framework continues to function as the main legal framework of emergency legislation. This highlights once more the close connection between the existing legal framework and historical experience.

I find it important to put the current legal developments within their proper context, by examining the rise of authoritarianism in connection to the proliferation of the state of exception during the last century. As a starting point, it is useful to note that the original legal mechanism in Romania providing for exceptional measures was the statute for the state of siege of December $10,1864 .{ }^{89}$ For its part, this text translates the content of the French version of 1849 relative to the measures instituted. What the Romanian statute provides for in this instance is the transfer of order maintaining powers from civil authorities to the military ones. ${ }^{90}$ Through the state of

\footnotetext{
${ }^{83}$ Tímea Drinóczi \& Agnieszka Bień-Kacała, COVID-19 in Hungary and Poland: Extraordinary Situation and Illiberal Constitutionalism, 8 THeORY \& PRAC. LegIs. 171, 189 (2020).

${ }^{84}$ Statute Confirming the Emergency Ordinance, supra note 68, at art. 8.

${ }^{85}$ Decree, supra note 67 , at art. 42 .

${ }^{86} I d$. at 43 .

${ }^{87}$ See Constitutional Court, Decision No. 152, May 6, 2020, 27-28 (Rom.).

${ }^{88}$ Elena Simina Tănăsescu, Covid-19 and Constitutional Law: Romania, in Universidad NaCiOnAL AUTÓNOMA DE México, COVID-19 And Constitutional LaW, 191-97, 192 (José Ma. Serna de la Garza ed., 2020).

${ }^{89}$ Statute for the State of Siege of 10 December 1864, in V. PANTELIMONESCU, STAREA DE ASEDIU: DOCTRINĂ, JURISPRUDENȚĂ ŞI LEGISLAȚIE 30-31 (1939).

${ }^{90} I d$. at art. 4.
} 
siege, the military authority could proceed with searches "whenever and wherever it will be deemed necessary." 11 It was also entitled to expel from the area declared to be under siege former convicts and persons without a legal residence therein. Moreover, it could withhold the publications and prohibit the assemblies which it "esteem[ed] to have the nature of inciting or supporting disorder." 92 The law also stated that all other constitutional rights, which were not suspended through the state of siege, continued to be exercised by citizens. ${ }^{93}$

Beyond these important provisions, what holds my interest is the fact that military tribunals are equally granted jurisdiction over crimes against state security, crimes against the Constitution, and against public order. ${ }^{94}$ Otherwise said, the state of siege does indeed institute an unbound exercise of power, namely the very act of suspension and the maintenance of order through military means. Yet, it also contains an element of normativity and provides for an administration of justice which, even if extraordinary, preserves at least a minimal reference to legality. It is as if amid the very cracks within the symbolic order defined and structured by the law, one can still find a liminal form of the articulation of power according to a normative structure. This is precisely what I think deserves a further analysis both within the history of legal practices as within contemporary settings, as it points towards the possibility of the law to articulate and be applied under the conditions of its very suspension.

It is this sphere of what one may call exceptional adjudication, that presents itself as the conundrum and the epitome for authoritarian adjudication. Understanding its symbolic function, its scope, and political stakes, as well as the ideological underpinnings of this final, and at the same time already distorted, rampart of legality is crucial for a contemporary assessment of authoritarian judiciary as it is for the conflation between military powers, police powers and the administration of justice. In light of the specific context, it is important to assess this liminal form of adjudication not as an obsolete historical practice that has been expunged from the functioning of the law, but as a paradigmatic one that was dormant within the understanding of legality. In this sense, my claim is that exploring these remnants of normativity under exceptional measures is not only helpful in tracing the continuities between normal regimes of legality and exceptional ones, let alone between rule-of-law based regimes and authoritarian ones, but also to enables us to inquire into the very structure of our normative frameworks. If indeed, a constant jurisprudential democratic historical trajectory posits the matter of legal validity as central to the functioning of our polities, on the path opened by the Kantian postulate of a "purity" of law, it is also possible to reconstruct a different politico-legal trajectory that emphasizes not only the "concrete order," but the efficacy of law itself within the functioning of the state.

\section{E. Exceptional Adjudication in Context}

Against this background, one should note the extraordinary origins of this peculiar legal institution. Traditionally in Civil law countries, military jurisdiction is extraordinary first because it is instituted as an exception from the rules regulating the "normal" or the regular functioning of the courts. Second because it is outside the order of the judiciary and of a specific order, the military. In post-war Europe, there has always been a tension between ECHR standards the functioning of military justice, insofar as "the ECHR not only de facto banned both the jurisdiction of military courts over civilians in times of peace and the presence of military judges in criminal trials against civilians, but also significantly curbed states' design choices regarding the structure of military

\footnotetext{
${ }^{91} I d$. at art. 6.

${ }^{92} \mathrm{Id}$.

${ }^{93} \mathrm{Id}$. at art. 8.

${ }^{94} I d$. at art. 5 .
} 
courts established to try members of the armed forces." 95 This type of judiciary situated at the limits of the regular application of the law was first instituted in Romania within a modern context as a part of the process of translation and acculturation of French legislation, that attempted to transplant - insofar as this is the right term — both the Civil and the Criminal Code, but also the institutions of military justice. ${ }^{96}$ The model was the French Code of Military Justice of 1857 who considered law as a vehicle for the modernization of the military and was perceived in the Romanian principalities as an important part of a necessary reform of the state on its way of embracing, or returning to, Western values. ${ }^{97}$ The basic features of this Code, arguably based on an institutional self-representation of the role of the modern army, as described by lawyers and the military at the time of its adoption were usually designated in terms of swiftness, dissuasion, and an exceptional character. As Jacques Langlais wrote in 1857:

the point is to punish; but more importantly it is to intimidate, to prevent; the example always has to be prompt, sometimes even urgent, and this is the reason why this exceptional justice should not be bothered with complicated rules that are not accounted for either by the simplicity of facts that it is called to judge, nor by the environment in which it acts, nor by the character of its jurisdiction. ${ }^{98}$

One should keep in mind that under the exception, jurisdiction according to the rules set out by the Code of Military Justice is extended beyond the ranks of the military, to citizens tried for crimes against the constitutional structure of the state, public order, and state's safety. This extension of jurisdiction is consistent with the perceived and intended aims of military justice, calling for swift and even brutal intervention. While brutality and a clear sense of derogatory attitude towards the existing law are documented in relation to either France ${ }^{99}$ and Romania, ${ }^{100}$ there is also a degree of leniency in the delivery of justice by military courts.

This is the case in the "normal" functioning of the courts trying military personnel, or within exceptional circumstances, because of either the political allegiance or security concerns raised by various categories of defendants. Moreover, an important aspect of military justice during the first years of the interwar period is the fact that the military personnel involved in its delivery was not required as a matter of law to have any level of legal training. As it has been pointed out, ${ }^{101}$ often martial courts cases did not follow the existing procedural and substantial demands for due process and legality.

Therefore, prima facie, the activity and role of military courts do present elements of strict hierarchy and authority based on a different form of legitimation than that of civilian courts, which might lead to arbitrary exercise of judicial power. Their stated role was to assure and instill cohesion amongst the ranks of the military, and within the conditions of the state of siege, to ensure an orderly conduct alongside military, or military-led operations of maintaining order. As the Second Chamber of the Romanian Court of Cassation noted in a judgment restating the jurisdiction of military courts in areas under the state of siege for crimes against constitutional order, military courts have a faster procedure, removing thus the solemn and slow forms of the ordinary procedure, that are very little compatible with the imperative and flexible needs, which

\footnotetext{
${ }^{95}$ David Kosař \& Lucas Lixinski, Domestic Judicial Design by International Human Rights Courts, 109 AM. J. INT'L L. 713, 727 (2015).

${ }^{96}$ The basis of this translation with regards military justice are to be found in a Military Criminal Code containing annex on the state of siege of 1852 .

${ }^{97}$ See Romanian Code of Military Justice (1873).

${ }^{98}$ Report on Legislation, J.O., 338 (June 9, 1857).

${ }^{99}$ Especially in territories under colonial rule in Northern Africa.

${ }^{100}$ Primarily in the newly acquired territories following the Treaty of Versailles.

${ }^{101}$ Odile Roynette, Les Conseils de guerre en temps de paix entre réforme et suppression (1898-1928), 73 VINGTIÈME SIÈCLE REVUE D'HistoIRE 51, 62-63 (2002).
} 
demand a prompt and decisive judgment, with the aim of assuring submission and preventing disorder. ${ }^{102}$

Yet the symbolic role of military justice is not exhausted by this functional assessment. Given that military courts operated during the interwar period in situations of political unrest, and have supported a specific understanding of state power, sovereignty, rights, and political freedoms, they have molded the experience of the interwar years. Moreover, they have brought within the very structure of legal history matters related to geopolitical and ideological concerns as well social tensions. In the constitutive year of the interwar era, in reaction to both the Bolshevik revolution in Russia and the proclamation of the short-lived Soviet Republic in Hungary, Romania has normalized its uses of the state of siege as a constant presence within the legal apparatus. As prominent constitutionalists of the time noted, this unprecedented recourse to the state of siege was nothing short of a regression towards a pre-modern practice. ${ }^{103}$

The interwar period is also a time in which the military presents itself as a political power able to support the national interest and in which military tropes spill within the dominant ideology and permeate legal ideology. After all, at the level of the general state ideology, Romania presented itself as a country of the cordon sanitaire meant to stop the spread of communism. ${ }^{104}$ The introduction of new criminal legislation in $1924^{105}$ breaking with traditional categories of act and attempt finds itself the apex of this trend. The proceedings following the Tatar-Bunar uprising when the local and foreign communist insurgents were allegedly supported by the Red Army in their contestation of state sovereignty sparked international attention as the largest criminal law trial in Europe judged in front of military courts. ${ }^{106}$ By the end of this period, military courts, as well as the state of siege, are the main devices through which social conflict is dealt with, especially in the newly acquired territories. ${ }^{107}$ As one astute observer of Central and Eastern Europe of that time noted, "the country lived under virtual martial law."108.

After a short period of inactivity, and following the financial crisis of 1929, military courts resumed activity under a new series of states of siege in an attempt to curb on one hand social unrest $^{109}$ and the overt rise of ultranationalism as a political force aiming to overthrow the constitutional order. Within this new context, this activity was further formalized by including and reframing a number of crimes within the functioning of the civilian criminal law apparatus, ${ }^{110}$ then by reframing the Criminal Code 1936. Later on, in 1937 the body of military judges was professionalized through a reform of the Code of Military Justice.

The instauration of the royal dictatorship by King Carol II in February 1938 was preceded by a declaration of the state of siege explicitly restating military jurisdiction over political crimes and

\footnotetext{
${ }^{102}$ Curtea de CasaȚie, a 2 a Cameră, Decizia Nr. 1308 din Decembrie 1930, in Codul JUSTIȚiei MILITARE ŞI LEGILE SPECIALE AFERENTE ADNOTAT CU JURISPRUdENȚELE INSTANȚELOR INSTANȚELOR DE CASARE Militară ŞI CIVILĂ ŞI CU NOTE DE DOCTRINĂ 37 (Constantin Manolache, T. TomiȚa \& Iustin Nistor eds., 1936) (emphasis added).

${ }^{103}$ Constantin Dissesco, L'évolution du droit public roumain, in LES TRANSFORMATIONS DU DROIT DANS LES PRINCIPAUX PAYS DEPUIS CINQUANTE ANS: LIVRE DU CINQUANTENAIRE DE LA SOCIÉTÉ DE LÉGISLATION COMPARÉE 300-301 (1922).

${ }^{104} J$. W. Wheeler-Bennet, The European Status Quo. 1919-1930, 7 Bulletin OF INT'L News 3, 7-8 (1930); Michael T. Florinsky, World Revolution and Soviet Foreign Policy, 47 PoL. SCI. Q., 204 (1932).

${ }^{105}$ Statute for the Repression of New Offenses to Public Peace of 18 December 1924, M.Of., No. 279, (Dec. 19, 1924).

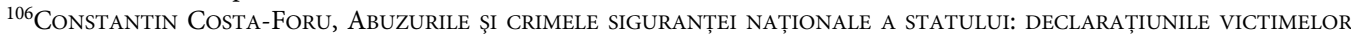
(1925); Henri Barbusse, Les bourreaux (1926).

${ }^{107}$ Charles Upson Clark, Bessarabia, Russia and Roumania on the Black Sea 223-31 (1927); William Brustein \& Amy Ronnkvist, The Roots of anti-Semitism: Romania Before the Holocaust, 4 J. GENOCIDE RES. 211, 226 (2002).

${ }^{108}$ Joseph S. Roucek, Social Background of Romanian Politics, 10 Soc. FORCES 419, 423 (1932).

${ }^{109}$ Sandra Halperin, War ANd Social Change In Modern Europe 196 (2004); Elis Neagoe-Pleşa, Gheorghe GheorghiuDej şi "procesul ceferiştilor" (1933-1934), in CoMUnişTII INAINTE DE COMUNISM 169-256 (Adrian Ciorqianu ed., 2019); Corneliu Pintilescu, Dezbateri publice privind decretarea stării de asediu, in 57 ANUARUL INSTITUTULUI DE IsTORIE “GeOrge BariȚiu” DIN CluJ-Napoca, 303, 315-18 (2018).

${ }^{110}$ Statute for the Defense of Order Within the State of 6 April 1934, M.Of., No. 82, (Apr. 7, 1934) (Rom.).
} 
stating that the exceptional measures "shall end when it will be considered appropriate." 111 The "salvation of the country" as well as the exceptional measures and military justice were central ideological tropes marking the activity of war-time Romanian legal life. Under the pro-Nazi dictatorship of General Antonescu, the main features of military rule and command occupied the central place of constitutional practice insofar as after the abdication of Carol II his son retained only symbolic reserved powers, while the General was entrusted with "full powers." 112 Romania joining the Allied powers in 1944 and King Michael's coup toppling the military dictatorship did not substantially change the recourse to exceptional measures and military jurisdiction over civilians. This practice survived in the first years of the communist post-war dictatorship, serving as an expedient mechanism for purging the "enemies of the state" for crimes against the constitution. ${ }^{113}$

It is only by the entry into force of the Criminal Code of 1968 and of the Criminal Code of Criminal Procedure, that military jurisdiction would be primarily circumscribed to military personnel, yet, a reserved jurisdiction over crimes against state security was retained. ${ }^{114}$ The Constitution of 1991 and Romania's joining of the ECHR system have limited even further the jurisdiction of military courts over civilians, yet issues of jurisdiction have continued to arise as late as $2006^{115}$ especially due to the late demilitarization of the police forces. To be sure, as things stand from the standpoint of the existing legislation, there is no longer such a special jurisdiction of military courts over civilians which would arise directly from the declaration of the state of siege or the state of emergency. Moreover, the legal nature of the military ordinances that make the substance of the legal reality of Romania's legal life under the pandemic seems to include the safeguard of oversight by civilian courts on grounds of legality. However, under the present conditions it is important to highlight to what extent these practices have molded both public and professional understandings and practices of legality as being supported by a dispositive that ultimately relies on military and security considerations.

\section{F. Conclusion}

The entanglement of law, politics, and military played a central role within the devaluation of liberal regimes of legality during the interwar and at least in the early years of the postwar period. It has actively sapped the normative pledges of the constitutional system and, under historical and ideological contingent factors, has ultimately ended up by taking part in the authoritarian re-writing of the law according to authoritarian commands. The point to be observed, it is that this gradual devaluation of legality was actually taking place under the guises of protecting its inner core by ways of introducing notions and concepts that were outside the sphere of the self-representation of the legal system.

Understanding the operation through which the law, in the practice of military courts acting under the suspension of legal protections, has been reconstructed is a central and urgent task insofar as these tropes of protecting identity, national values, and specific traits of a polity by reference to security measures and security-based concepts is once again resurrected. It might be indeed the case that the activity of the military in contemporary democracies is highly formalized and indeed finds itself under the scrutiny of both civilian courts and public opinion. However, what we are still dealing with is the ways in which this experience has shaped the legal and constitutional imaginaries of lawyers - be they scholars and practitioners - and has insinuated

\footnotetext{
${ }^{111}$ See id.

${ }^{112}$ Decree-Law of 8 September 1940 Concerning the Office of the President of the Council of Ministers and the Royal Prerogatives, No. 3072, M. Of., Nr. 208, (Sept. 8, 1940) (Rom.).

${ }^{113}$ See e.g., Military Tribunal of the 2nd Territorial Region, Criminal Sentence No. 1988, (Nov. 11, 1947) (reprinted in Scânteia, No. 973, (Nov. 13, 1947) as “Textul oficial al sentinței în procesul conducătorilor fostului PNȚ”).

${ }^{114}$ Code of Criminal Procedure of 1968, art. 26, B. Of., No. 145, Nov. 12, 1968.

${ }^{115}$ Maszni v. Romania, App No. 59892/00 (Apr. 24, 2012), http://hudoc.echr.coe.int/app/conversion/docx/?library= ECHR\&id=001-108754\&filename=CASE\%20OF\%20MIHAI\%20TOMA\%20v.\%20ROMANIA.docx\&logEvent=False.
} 
itself in the construction of key concepts such as territory, population, or social dangerousness. Under the present circumstances, in which an "imminent danger of a calamity" has been identified and declared as a matter of positive law, the reemergence of authoritarian adjudication is yet another threat to the democratic role of the judiciary. While limiting recourse to military and exceptional justice was a constant concern in the post-war era and following the collapse of communism, and indeed securing civil democratic control over the military was perhaps one of core institutional achievements of our times, in the current context these gains do not seem secured. Recent developments in France, where former members of the military threatened in a thinly veiled manner with recourse to civil war, ${ }^{116}$ the growth of a rhetoric calling for "swift" justice, emerges against the background of emergency measures and the specific legal and symbolic uncertainty that it brings within polities. The daily routine of what has been coined as the "permanent emergency,"117 if not a permanent "state of exception,"118 doubled by ideological tropes such as national sovereignty and disdain for legality, ${ }^{119}$ should prompt us to question even further what is precisely the nature of authoritarian adjudication by exploring the historical contexts it has been experienced.

\footnotetext{
${ }^{116}$ Constant Meheut, New Military Letter Warning of 'Brewing' Civil War Prompts Outrage in France, N. Y. TimEs (May 12, 2021), https://www.nytimes.com/2021/05/12/world/europe/france-letter-military-civil-war-warning.html.

${ }^{117}$ Alan Greene, Permanent States of Emergency and the Rule of Law: Constitutions in an Age of Crisis 209214 (2018).

${ }^{118}$ See AGAmBEn, supra note 34.

${ }^{119}$ Bojan Bogaric, Two Faces of Populism: Between Authoritarian and Democratic Populism, 20 GERMAN L. J. 390, 395-96 (2019).
}

Cite this article: Cercel C (2021). Law, Politics, and the Military: Towards a Theory of Authoritarian Adjudication. German Law Journal 22, 1192-1208. https://doi.org/10.1017/glj.2021.66 